\title{
The Powers of Australian Retail Workers as a Section of the Global Working Class
}

\author{
Pooya Karambakhsh, University of Sydney, Australia
}

\begin{abstract}
The wide application of the power resources approach has shown its strong capabilities in enabling strategic labour research that can also benefit activists. Nevertheless, the approach has been criticised for ignoring how power is used. This article argues that Steven Lukes's radical view on power can address this issue. His three-dimensional view considers power in direct conflicts, agenda setting, and the situations in which an actor's preferences are shaped by another. A key strength of this view is that it can be used to unravel systemic effects and underlying sources of conflicts. In this article, the Lukesian framework is applied to the condition of Australian retail workers as an example of the precariat. It is argued that retail workers have underestimated powers in direct confrontations with employers, and that the legal and institutional frameworks provide them with some support. The analysis indicates that capital's efforts to form preferences, theoretical foundations and ways of thinking have contributed to substantially pre-empting retail workers' agency. However, it also shows that there is nothing inevitable about this situation.
\end{abstract}

\section{KEYWORDS}

power; dimensions of power; retail; workers; Australia; class

\section{Introduction}

Power is an essentially contested concept, widely discussed and variously treated in different contexts. In recent decades, the power resources approach (PRA) has been developed and widely used by labour scholars and activists to analyse the powers of workers. The basic premise of this approach is that, within the antagonistic capital-labour relations, workers can defend or advance their interests by the collective mobilisation of their resources. The PRA divides workers' powers into general categories of structural/economic, associational, institutional and societal (Schmalz, Ludwig and Webster, 2018: 113-116). The PRA can be easily grasped and used, and can enable the strategic research needed by labour activists (Gallas, 2018: 348).

Despite these strengths, the PRA seems to suffer from critical limitations. Gallas (2018: 349) argues that the PRA analysis is not truly relational; it only focuses on how power is used and it ignores what the power is used for. It thus considers a win to be any strategy that leads to the achievement of set goals of a group of workers, irrespective of what it does to the working class as a whole. Similarly, Nowak (2018: 353) argues that the PRA can identify the most useful power resources but does not explain to what end they can be used.

In this article, I argue that Steven Lukes's (2005) radical view on power has the capacity to address the PRA's limitations. This view seeks to provide a broad understanding of power, which is theoretically and politically radical and, at the same time, operational and useful for empirically assessing hypotheses (Lukes, 2005: 1, 14). To demonstrate its capability, I apply this view to the 
conditions of Australian retail workers. Although the retail industry is quite broad and the conditions of workers vary significantly across sections, the overall picture of the industry epitomises contemporary precarious work, particularly that of retail workers in advanced economies, with characteristics such as low wages, underemployment, and "flexibility" (Luce, 2013: 7-9; Coulter, 2014: 1-2; ILO, 2015: 2-4, 10-11; Campbell and Price, 2016: 320-322). I use Lukes's three-dimensional framework to better assess the workers' seeming powerlessness, reflected in their poor working conditions. The analysis shows that this framework not only has the capacity to evaluate power in direct conflicts but also to unravel systemic issues underlying and engendering those conflicts, and thus to point out the ultimate aims of everyday struggles.

\section{Dimensions of Power}

Lukes (2005) distinguishes three views on power as one-, two- and three-dimensional. From the one-dimensional, "pluralist", viewpoint, "A has power over B to the extent that he can get B to do something that B would not otherwise do" (Dahl, 1957: 202-203). It focuses on decision-making behaviours concerning observable conflicts over subjective interests. The two-dimensional, "reformist", view begins with a critique of the first view for misleadingly celebrating the pluralistic features of American politics and ignoring as a case of power when A's efforts are devoted to establishing values and institutions that would limit public and political issues to those innocuous to A. To address these issues, the second view considers observable (overt or covert) conflicts over subjective interests as well as both explicit preferences and implicit grievances (Lukes, 2005: 19, 22-25). It seeks to identify potential issues that nondecisions prevent from being actual. In this view, nondecisions are themselves decisions that suppress challenges to the interests of the decision-maker.

The one- and two-dimensional views of power follow Weber's methodological individualism, in which power is "the probability of individuals realizing their wills despite the resistance of others" (Lukes, 2005: 26). Both views exclusively associate power with actual, observable conflict and ignore latent conflicts of interest. Thus, neither can properly analyse collective actions by groups or reveal "systemic" or organisational effects. Even the two-dimensional view overlooks situations in which power relations deny the formation of grievances, for instance through the naturalisation of the status quo. In other words, the first two views cannot account for when $\mathrm{A}$ influences, shapes or determines B's very wants. For Lukes (2005: 27), "the most effective and insidious use of power is to prevent such conflict from arising in the first place".

To overcome the limitations of the first two views, Lukes's three-dimensional, "radical", view of power seeks to address not only what the two views include but also what they exclude. To that end, it considers decision-making and nondecision-making, issues and potential issues, observable (overt or covert) and latent conflicts, and subjective and real interests (Lukes, 2005: 29). The differences between the three dimensions of power can be better illustrated by an example. Assume that $\mathrm{A}$ and $\mathrm{B}$ have preferences of $\mathrm{a}$ and $\mathrm{b}$, respectively. If $\mathrm{A}$ gets $\mathrm{B}$ to opt for $\mathrm{a}$, for example by using threat, then $\mathrm{A}$ is exercising the first dimension of power. If $\mathrm{A}$ manages to prevent $\mathrm{b}$ from becoming an option for consideration, then she is exercising the second dimension. However, if she succeeds in shaping B's preferences in favour of a or in preventing B from developing, considering or even thinking about $\mathrm{b}$, then she is exercising the third dimension of power.

The notion of interests is critical to Lukes's understanding of power. He argues that the onedimensional view considers people's interests as what they actually want or prefer, while for the two-dimensional view the interests can be actual, deflated, submerged or concealed wants and preferences. In the three-dimensional view, people's preferences may be the products of power 
relations and, hence, their real interests are those preferences that they would have if they had a real choice.

Hay (2002) argues that the third dimension's dependence on "real" interests entails the idea of false consciousness, which, in turn, implies that the dominated is the "dupe" of the powerful and incapable of identifying her own interests. Hay (2002: 179) finds this implication "deeply condescending", "logically unsustainable", "politically offensive" and "implying a privileged vantage-point for the enlightened academic". Lukes (2005: 37, 146-149) argues that there can be an empirical basis for identifying real interests where B is relatively autonomous and independent of A's power, for example, through democratic participation. While acknowledging analytical challenges associated with the notions of "false consciousness" and "real interests", he suggests those difficulties can become less serious by simply taking "real interests" as a function of explanatory framework. For instance, in a "materialist" framework they can mean material interests, or in a "rational choice" framework they can indicate individuals' best interests. Lukes suggests viewing real interests as a way to identify "basic" or "central" capabilities, precluded in existing arrangements. For him, real interests and false consciousness imply an external standpoint, highlight the cognitive power to mislead, and are not the same as the "arrogant" idea of privileged access to the truth.

Associating power with systemic issues and collective will, the radical view has similarities with Marxists' view on power. From such a point of view, Palermo (2016: 6) suggests that the point of analysing power is to uncover "systemic effects" and to find "non-observable structures and mechanisms" that govern all forms and notions of power. Social coercion stems not from individual relations but from class relations. In the same vein, Jessop (2012) considers power relations as manifestations of particular configurations of class domination rather than interpersonal phenomena that occur at the surface. Power relations are entangled with social relations such as social control over resource allocation, the appropriation of surplus value, the social division of labour, property relations and economic exploitation. Hence, the role of the state is quite central to this view, not only in terms of political power but of class power in general (Jessop, 2012: 1, 7). Power, in this sense, is socially structured and works to secure the continuity of status quo social relations. As Isaac (1987: 3-4) aptly puts it, "rather than A getting B to do something B would not otherwise do, social relations of power typically involve both A and B doing what they ordinarily do".

Lukes's view retains an agentic tendency, denoting an account of freedom rather than considering power as "a network of boundaries that delimit, for all, the field of what is socially possible" (Hayward, 2000: 3-4). Similarly, Nigam (1996) advocates a productive and agentic approach to power, viewing it as primarily creative and productive, associated with freedom, action and praxis. Although power in collective action requires innumerable free wills to be somehow constrained and forged into a collective will, it is distinguished from structures because it is in agents' power to act or not to act. A total structural determinism leaves no place for power (Lukes, 2005: 57). As the debate between Hayward and Lukes $(2008: 10,17)$ highlights, the importance of power analysis is to identify and devise methods of change. While the agent-centric view may overlook "some subset of significant and remediable social constraints on human freedom", the structural view may overlook "particular agents who are responsible for the constraints" in question.

In short, power relations in Lukes's radical view can be analysed at three levels or dimensions. The first dimension involves direct, observable conflicts while the second includes grievances and whether they are granted entry into the conflict phase. The third dimension considers the situations in which the powerful can shape the preferences of the opponent and thus pre-empt the formation 
of opposing interests. This three-dimensional view enables assessing power relationships beyond successes and defeats in stand-alone campaigns and can turn the focus onto what power is used for. In this sense, analyses based on this framework can address the limitations of the power resources approach. To demonstrate this capability, this article assesses the powers of Australian retail workers. The next section outlines the conditions of these workers and the economic characteristics of the industry.

\section{The Economic Characteristics of the Australian Retail Trade}

The Australian retail trade is a relevant case for the study of workers' power because of its deep integration within global value chains and its workers epitomising what Standing $(2016: 1,8)$ labels the global precariat. He suggests that with global economic restructuring and the rise of work flexibilisation that began in the 1970s, risks and insecurity have been increasingly transferred to workers and their families. The neologism combines the "precarious" and the "proletariat" to convey the condition of a class-in-the-making, which has yet to become a class-for-itself. (For indepth discussions on the notion, see Global Labour Journal, May 2016, Special Issue on the Politics of Precarity: Critical Engagements with Guy Standing.)

Australian retail appears typical of the industry in a core or semi-periphery country in terms of employment size (about 10-15 per cent of the national workforce) and low profit margins (Luce, 2013: 4). With about 1.3 million employees, equivalent to 11 per cent of the national workforce, retail is the second-largest industry in Australia (ABS, 2018h). From 2014 to 2017, its average profit margin was just under 4.6 per cent, less than half of all industries (11.0 per cent) (ABS, 2018a). The low profit margins drive retailers to pursue methods to cut costs. A common practice is to cut wages and other indirect costs, such as training, despite the fact that labour costs constitute only about 10 per cent of the overheads (Price, Bailey and Pyman, 2014). As a result, retail workers' average wage is the second lowest in the Australian economy. The pressure, however, is not limited to their wages. Australian retailers increasingly use casualisation and "low road" employment methods (Luce, 2013: 6), providing few or no benefits to employees, deskilling work and operating with high employee turnover. In 2010, only 15 per cent of retail workers had been with their employer or business for more than ten years, compared with the national average of 24.4 per cent (Productivity Commission, 2011: 385). The level of labour turnover varies significantly between enterprises but, for instance, Woolworths Group's (2017: 64) employee turnover in 2017 was 27 per cent.

In 2015, 39 of the top 250 global retailers had Australian operations (Deloitte, 2017). The majority foreign-owned retailers employed about 46000 people and earned AU $\$ 24.7 \mathrm{bn}$ in revenue, equivalent to 8.5 per cent of the industry's AU\$291.4bn turnover (Bingham, 2016; ABS, 2017b). Meanwhile, Australian retailers are quite active abroad. In 2013, Australian wholesalers and retailers employed about 14000 people in the United States (US) and the European Union (EU), and had about AU $\$ 10 \mathrm{bn}$ revenue, equivalent to 3.8 per cent of the industry's AU $\$ 264.7 \mathrm{bn}$ turnover (ABS, 2015, Bingham, 2017).

The industry is deeply embedded within global supply chains and value networks. The supply chains of the top two Australian retailers in 2018, Wesfarmers Limited and Woolworths Limited, virtually span the globe, including countries in Asia, Europe, North America, Central America and Oceania (Wesfarmers, 2017b, 2018; Woolworths Group 2017, 2018).

Retail employment has risen significantly over the past decades, increasing from just over 700000 in 1985 to more than 1280000 in 2018. This growth has been quite volatile, without necessarily following the fluctuations of national trends (ABS, 2018h). It also varies among retail 
sectors. Between 1996 and 2011, employment in department stores fell by 18.5 per cent while it rose by 36.7 per cent in supermarkets and grocery stores (Productivity Commission, 2011).

Retail is the final step of the distribution process, acting as an interface between manufacturers or wholesalers and the general public. Despite differences between countries, over the past decades the industry has been generally moving towards consolidation and the growth of large retailers. To reduce cost and secure growth and profitability, these firms implement new technologies and methods. A method that has been widely used in the industry is flexibilisation, keeping the size of the workforce to the absolute minimum by "lean" staffing and relying heavily on part-time and casual employment (ILO, 2011: 5, 11-12; Luce, 2013: 7, 8). The trend towards flexibility is quite noticeable in Australian retail.

According to the Productivity Commission (2011), the Australian government's independent advisory body on socioeconomic and environmental issues, the retail workforce is youthful with a "preference" for part-time employment. The average age of 35 years is only older than that of accommodation and food services employees, who are on average 30 years old (ABS, 2019). Those who work 29 hours or less per week constitute 23 per cent of the retail workforce compared to about 14 per cent of the employees in all industries. The top reasons for choosing part-time work in retail are participation in education (44 per cent), caring for children (16 per cent), and a preference for part-time work (14 per cent). The paradox here is that although many retail workers choose the industry for flexibility, fewer than 35 per cent actually have a say in their start and finish times, compared to all industries (42 per cent) or the similar industry, the wholesale trade (46 per cent) (Productivity Commission, 2011: 382-385).

Despite the lack of comprehensive data, the available evidence indicates that the retail workforce is quite diverse in terms of gender, sexuality, ethnicity and so on (Wesfarmers, 2017a: 17; Woolworths Group, 2017: 6). Between 8 per cent and 11 per cent of migrants - born in the UK, New Zealand and Asia - work in retail, which is quite similar to the Australian-born and the national average (DIBP, 2014: 18). Female workers constitute 52.6 per cent of the retail workforce, which is higher than the national average of 46.9 per cent, but the full-time employment is biased towards men. Women's share of full-time employment (42 per cent) is less than their male counterparts (58 per cent) (ABS, 2018g). Two-thirds of female retail employees work part-time compared to only one-third of male employees.

The rate of casual employment is also high. As of 2018, casual employees and other workers without paid leave entitlement constituted 38 per cent of the retail workforce, 1.5 times the overall average of the Australian workforce (ABS, 2018d). Women are again disadvantaged. In 2017, 24 per cent of male workers were not entitled to paid leave against 34 per cent of female workers (ABS, 2018e). Although casuals' lack of paid leave is somehow compensated by higher hourly rates, in the long run this type of employment disadvantages workers. Casual and insecure employment can create a barrier for the future of workers. "Once a worker has commenced insecure employment, it is difficult to move to secure employment" (ACOSS, 2012).

On average, retail workers are less educated and have fewer skills than the rest of the Australian workforce. According to the Productivity Commission (2011: 381-382), in 2009 about 60 per cent of retail workers were without a post-school qualification compared to 40 per cent in all industries. In retail, about 21 per cent had a diploma and above, and 20 per cent had certificate qualifications. In all industries, the proportions were 38 per cent and 22 per cent, respectively. The Productivity Commission's report also suggests that retailers are less likely to train their employees. In 2009, less than 25 per cent of retail workers had received training in the past year compared to more than one-third of employees in all industries. Full-time and permanent staff comprise the largest share of those who receive training. However, they are still much less likely to receive 
training compared to their counterparts in other industries (30 per cent compared to 42 per cent). The report suggests that "this could be due to lower skill requirements for the industry" (Productivity Commission, 2011: 375).

Wages in retail are quite low. The median weekly earning is AU\$700 and the mean is AU\$789, which is about 65 per cent of the weekly earnings of an average Australian worker. These figures mean that more than half of retail workers earn less than the national minimum wage from their main occupation. According to the Fair Work Ombudsman (2019a), the current national minimum wage in Australia is AU $\$ 19.49$ per hour or AU $\$ 740.80$ per 38-hour week. With a higher share of permanent and full-time employment, men earn more than women with a median of AU $\$ 895$ per week against $\mathrm{AU} \$ 600$ (ABS, 2018d).

Retail workers' conditions of employment, like other Australian workers, have been regulated by the Fair Work Act since 2010 (DEEWR, 2012). The Act established ten National Employment Standards (NES) as a new safety net; they outline workers' minimum employment entitlements including working hours, leave, employment termination, flexible work arrangements, consultation, dispute-settling and "unlawful terms" (Fair Work Ombudsman, 2019b). The NES cover about 96 per cent of the private sector, with the public sector being formally under state legislation. The Fair Work Act also relies on the awards system, consisting of 122 legal documents (modern awards) which define minimum wages and conditions of employment, in addition to NES (Fair Work Ombudsman, 2018). These continue to act as benchmarks for the "better off overall test" (the BOOT), which ensures enterprise agreements do not reduce the wage and conditions of workers below awards.

Within the framework of the Australian industrial relations system, the wages and working conditions of most ( 69 per cent) retail workers are covered by the awards and collective bargaining. This level of coverage has been fairly constant over the past decade and about 10 per cent above the national average (Fair Work Commission, 2013: 19; ABS, 2017a). Some researchers, such as Price et al. (2014: 755), consider this to be an achievement of the main retail union, the Shop, Distributive and Allied Employees' Association (SDA), which is Australia's largest trade union with more than 210000 members (SDA, 2018: 1). The union is a member of the Australian Council of Trade Unions (ACTU), the peak body of trade unions in Australia (ACTU, 2018), and the UNI Global Union, with several of its members on the executive board of the UNI (UNI, 2018). The SDA is also an affiliate of the Australian Labor Party (ALP) and several of its previous officials have eventually become federal and state Labor politicians (APH 2018a, 2018b).

A key challenge facing the SDA is retail's high workforce turnover among workers and managers. To tackle this challenge, the union relies on good relationships with employers. It first establishes a firm agreement and good relationship with the organisation, and only then begins the bargaining process. The SDA's frame of action is built on patience and persistence and, thus, relies on officials' rather than members' agency. Through this approach, the SDA has established stable and enduring collaborative relationships with major Australian retailers (Price et al., 2014; Bailey et al., 2015). The SDA takes a servicing approach, almost never pursues confrontations, shuns militancy, avoids media attention and presents the image of a "bargaining union that rarely campaigns" (Bailey et al., 2015: 7). Hyman (2001: 10) identifies three ideal types of unionism: unions that target the labour "market" and act as interest organisations; those that target the "society" and seek to raise workers' status and advance social justice; and those that act as "schools of war" in the class struggle between labour and capital. Viewed from this perspective, the SDA's approach is mainly oriented to market, less to society, and not at all towards class (Price et al., 2014: 15).

In short, retail is a large industry in terms of employment, revenue and the spread of supply 
chains, but it has low profit margins. Considering gender, age, sexuality, ethnicity and even nationality, the retail workforce is quite diverse. On average, however, it is mostly female, young, part-time, casual and with low wages. Compared to the rest of the Australian labour force, retail workers are less skilled. They seem to fit the image of the inevitable losers of the "new economy" (Wood, 1995: 49; Castells, 2010: 77), with little power to change their conditions. The next section engages with this depiction of powerlessness more critically and offers an evaluation of the workers' powers using Lukes's radical view.

\section{Reassessing Retail Workers' Power}

To analyse the powers of retail workers, the behavioural tendencies of the one- and twodimensional views necessitate a focus on observable conflicts. In this sense, workers' power involves winning conflicts, setting agendas and determining what counts as legitimate conflict. Most common, observable conflicts between workers and employers arise over wages and working conditions, including hourly rates, casual or permanent status, part-time or full-time employment, leave entitlement, the number of weekly working hours for part-time and casual employees, and public holidays. Such conflicts are often handled directly between workers/unions and employers through negotiations and enterprise bargaining. If they fail to reach an agreement themselves, the Australian industrial relations system outlines provisions for state arbitration (DEEWR, 2012: 52). Moreover, conflicts can elevate to the political sphere in the form of policy debates, for instance over industrial relations or health and safety issues.

Based on the employment size of the enterprise, conflicts over wages and working conditions can arise in two general scenarios. First, conflicts between workers and large retailers are mostly facilitated by unions. In such cases, workers are confronted with giant corporations with vast resources far beyond theirs. As described above, retail workers are among the poorest wage earners in Australia (ABS, 2018c) and many of them are casuals. Their precarious employment leaves them unequipped to sustain long periods of industrial action. With less than AU $\$ 49 \mathrm{~m}$ of total equity about 1 per cent of the after-tax profits of Wesfarmers (2017a: 4) and Woolworths Group (2017: $8)$ - the SDA (2017a) lacks resources to support major strikes.

In conflicts between workers and small retailers, unions might have capacity and resources superior to that of employers. However, small retailers typically opt to avoid direct confrontation or enterprise bargaining and instead rely on the awards system to pay the minimum wage (SDA, 2017b). Although the significance of small retailers can be negligible individually, collectively they comprise a notable section of the industry. Their share of retail value added is 34 per cent and they employ about 38 per cent of the industry's workforce (ASBFEO, 2016).

Second, despite lacking material resources to directly confront large retailers, workers might be able to develop their connections to other actors. Because retail has daily interactions with the entire population, strikes at strategic points could create significant and highly visible disruptions. Such strikes would involve forces from outside the retail industry. If workers incorporate this tactic carefully, those forces might provide the support needed to win their battles.

Moreover, if workers elaborate their problems and demands in universal terms, appeal to the working-class essence of the general public and mobilise the support of consumers, they can also consider consumer boycotts as a supportive option. With fierce competition among retailers and the centrality of the consumer in contemporary global capitalism, this tool might be effective in conflicts with large retailers. Despite severe legislative constraints - for example, the Competition and Consumer Act 2010 (Office of Parliamentary Counsel, 2017) - it might be possible to mobilise the support of workers in other industries, or even other countries. 
In both scenarios, retail workers can benefit from elevating the issue to the public sphere, presenting their case to the wider community and appealing to the working-class essence of consumers and other actors. By involving the broader community, retail workers might be able to tap into powers and capacities beyond their own. Articulating their grievances and demands in more global and universal terms would help to reinforce their alliances, making it easier to mobilise support to improve their conditions. The outcomes of the SDA's participation in the Sydney Alliance to protect public holidays (Holgate, 2015) and in the Bangladesh Accord, despite their limited ambitions, demonstrate the effectiveness of such strategies (Zajak, 2017).

The political sphere becomes indispensable if retail workers are to involve other actors. By escalating their grievances to the political arena, not only can workers get the attention of the wider community, but they can also influence policies related to their employment. Such policies are critical to workers' second dimension of power, as they determine the target of negotiations, bargaining or strikes. The low gross value-added of retail, which is about 4.4-4.5 per cent of the national economy (ABS, 2018b: 68-69), could pose a challenge in attracting political attention but this is compensated for by the industry's sizeable employment (ABS, 2018f) and its direct interaction with the everyday life of all Australian residents. Taking advantage of these features, retail workers could grasp the attention of the media, the public and, ultimately, policy-makers.

In short, there are options for retail workers to exercise their first and second dimensions of power, including domestic strikes, consumer boycotts or even solidarity strikes along retail supply chains. The persistence of poor conditions for so long could indicate the insufficient use of power along these dimensions. However, workers' disengagement and preference to leave the industry instead of fighting to improve the conditions prevent any effective testing of such options. Here, the role of the SDA, as the main union in the sector with a high membership density particularly in supermarkets, is not negligible. Bailey et al. (2015: 12-13) underline the union's ideology and the Australian institutional context, particularly the single-employer bargaining framework, as key reasons why the high membership and collective agreement coverage have not led to better results for workers. The union's ideology is reflected in its strategies that "de-emphasise equity and voice", and thus discourage rank-and-file participation. The result is a low union democracy, which in turn could explain why the same conservative national leadership has been in power for the past few decades (Price et al., 2014: 753 ,755, 757). The union's approach seems to be in line with the arguments that the problems of contingent labour require "upscaling", which shifts class-based struggles from the industrial to the political arena. This shift means that when the ALP is in opposition (18 years out of the last 24 years), union agency is significantly weakened (Bailey et al., 2015: 12). As is argued below, all these factors are closely related to the third dimension of capitallabour power relations.

The assessment of the third dimension of power is more challenging than the first two dimensions because it also considers unobservable conflicts and systemic effects. It might, however, be traced in its effects on various aspects of workers' employment. Returning to wages and working conditions, the third dimension of power can be seen in how the wages are determined, how the debates on these issues are framed and what forms the foundations of arguments. Wages and salaries are commonly associated with productivity and skillset. While skill scarcity is often cited as the cause of high salaries, low productivity is used to justify low wages. For instance, the Business Council of Australia explains wage stagnation based on a lack of growth in productivity, promising to increase wages when productivity begins to rise (Greber, 2017).

Associating wage levels with productivity is fair from the viewpoint of employers, for whom labour is just another factor of production, like tools or raw materials. From this perspective, retail workers earn less than most other workers because labour productivity is low. As of 2009-2010, 
labour productivity, measured as value-added per hours worked, was AU $\$ 28$ compared to AU $\$ 55$ for the entire economy (Productivity Commission, 2011: 59-60). If the productivity-wage nexus is accepted, it becomes difficult to demand retail wage rises that do not follow productivity proportionality.

The productivity-wage nexus implicitly presumes free markets and exchange. However, earning in proportion to productivity is only fair for workers if they freely choose the industry of their employment. Based on such assumptions, retail workers would choose this low-paying industry because of the level of their skillset, their other commitments or their preference for retail work. Assuming there were a variety of industries available for them to choose from, they would either be physically or intellectually incapable of gaining the skills for higher-paying jobs, would choose not to gain those skills because they had other commitments (such as children or study), or simply enjoyed the features of retail work. However, the assumption of free markets and exchange can be questioned because it ignores entry barriers and biases based on arbitrary features such as gender, sexuality, citizenship status, ethnicity or physical attributes (Dunn, 2010: 19). It also ignores the fact that in many regional areas few jobs and types of employment are available to workers. If workers cannot relocate to another region with more opportunities - for example, for family reasons - then working in the only geographically available option is not a real (free) choice. Moreover, the arbitrariness of formal qualifications may pose another barrier to workers in finding jobs related to their education or training, hence forcing them to work as unskilled or low-skilled labour. This issue is more pronounced with migrant workers, whose qualifications may not be officially recognised in the destination country.

This semi-micro approach - which views workers' wages as costs to the business and leaves them to be determined by labour productivity, the demand for the skills and the return to capital - is not the only possible view. An alternative, mainly macro, approach would consider wage determination from a national viewpoint and, for instance, link wage rises to economic growth (Coorey, 2017). Instead of putting the onus solely on workers, this approach holds the state and all the national socioeconomic structures responsible. If workers do not have skills for high-paying jobs, there might be factors other than their free will at play, such as poverty, geographic constraints or barriers to quality education. Moreover, the low labour productivity in retail, like other service industries, is mainly because of its service nature and not necessarily the efficiency in using inputs (Productivity Commission, 2011: 59-60). Being a service should not render an industry unnecessary nor be the basis for punishing its workers. Connecting wages to the performance of the entire economy could be a more equitable option.

While this type of argument - taking the perspective of the state or the national economy - is almost ignored in support of pay rises, it is used to advocate pay cuts. A clarifying example is the reduction of the Sunday penalty rates for hospitality and retail workers. Penalty rates are the rates that apply to work conducted outside normal working hours, including weekends, public holidays, overtime, and late-night or early-morning shifts (Fair Work Ombudsman, 2019c). In 2017, the Fair Work Commission ruled in favour of reducing the Sunday and public holiday penalty rates of the lowest wage earners in Australia, that is, hospitality and retail workers (ABC, 2017). At the surface, it is a simple case of the exercise of the first and the second dimensions of power, in which employers won the conflict over wages by changing the rules. However, the fundamentals of the arguments put forward in support of this change point to a deeper level of power relations.

The Productivity Commission $(2015: 461,465)$ argues that lowering the Sunday penalty rates potentially improves productivity, increases the working hours of current workers and raises employment. The main beneficiaries of the decision, the report suggests, are consumers. Although it concedes that with the fall of Sunday penalty rates some workers will be "much worse off', it 
claims that it is the role of the tax and transfer system, and not penalty rates, to support those on a low income (Productivity Commission, 2015: 461). This argument employs a macro perspective to consider the problem and recognises the role of the tax and transfer system to address inequality issues. It implies that the employer has no responsibility to promise a living wage to workers, but rather that it is the role of the state to do so by supplementing wages with transfers. In other words, this argument shifts the burden from capital to the state. The Commission's argument also relies on what Sklair (2016: 338) names "the Achilles heel of global consumerist capitalism", that is, consumer sovereignty. The argument aims to favour and advance the benefits for consumers. However, in doing so, not only does it favour consumers over workers but ignores that retail workers are at the same time retail consumers. Undermining the purchasing power of these people ultimately undermines the whole argument.

A year after the verdict, according to the same organisations that pushed for the cuts, lowering Sunday penalty rates "failed to create one new job" (Hannan, 2019). The failure could be attributed to incorrect or incomplete modelling. However, even if the modelling were sound, it would be one among many with potentially different outcomes. For instance, an economic model of the retail industry in the United States demonstrates that raising the wages of retail workers leads to economic growth and increases productivity (Ruetschlin, 2012). Even more, economic models are always, explicitly or implicitly, based on ontological, epistemological and methodological premises of some schools of economic thought. The Productivity Commission's report is based on the prevalent, mainstream neoclassical economics.

This school of economic thought forms the basis of most official economic analysis and modelling in Australia and many other countries around the world. Its dominance is a testament to the success of capital's agency and exercise of power over past decades. Neoclassical economics, which completely ignores power relations and assumes perfect competition, "the supreme optimality of the market" and "the ever-perfect invisible hand" (Shaikh, 2016: 4), does not simply seek to analyse the system. It justifies and perpetuates the system. By arguing within this school of economic thought, workers and their supporters, consciously or unwittingly, accept and reinforce the fundamental premises, which favour capital or, at least, approach problems from the viewpoint of capital. In other words, the power of capital rests on, and is indeed reproduced by, the same language that workers use to argue against it.

Other schools of economic thought point towards alternatives. For example, a Marxist perspective suggests that evaluating retail workers' situation requires recognising that all debates, conflicts and struggles are ultimately within and based on capitalist relations, including its wagelabour system. Exploitation and the appropriation of surplus value by the owners of the means of production are essential elements of the system.

A key contributor to the intactness of the pro-capital fundamentals and an obstacle to systemic change is the image of powerless labour. It is often propagated by political and ideological motives to demobilise workers' agency (Silver, 2003: 15-16; Dunn, 2004: 178). In many cases, workers' agency, rather than structural features, is the determining factor in resisting the power of capital and establishing the rights and benefits of workers. Agency can be critically impacted by the sociopolitical discourse of the time. Although discursive formations can be seen as structural features of contemporary society, and thus appear as "given", change is still possible, no matter how deeply embedded those features are. A first step to engender such change is to question the objective status of such structures and to realise they are the results of human interactions in the past (Bieler and Morton, 2001: 26).

Here, the instance of Australian retail workers is a case in point. As discussed above, the poor conditions of retail work lead to a vicious cycle. There is, however, nothing inevitable about the 
cycle. It is the result of the interaction of social structures and workers' (lack of) agency. Although structures are recurring and relatively durable social relations, they are not eternal and do change over time. Retail workers, like other social actors, can contemplate past actions, plan for future steps and alter the social structures that affect their conditions. Understandably, they do not have full control over all the social structures that condition their employment. Some national and global structures cannot be changed by their actions alone. However, they can be altered by the collective action of multiple actors and stakeholders at various levels. To do so, retail workers can potentially mobilise the support of other workers, including academics, policy-makers, journalists and so on. For global structures, they also need to rely on the support of workers in other countries, with whom they might be connected via the broad supply chains of the retail industry.

Of course, this more radical view of power also highlights the limitations of strategies specific to retail workers and calls for a class-based, expansive strategy. As long as the fundamentals are untouched, the system reproduces itself; the domination of capital continues, and all the conflicts over wages and working conditions remain at the surface. Any wins for workers in these struggles remain superficial, tentative and temporary. As history has repeatedly shown, such changes can be reversed with subsequent shifts in the balance of power. Thus, to engender lasting changes, campaigning over day-to-day issues should be coupled with struggles to effect systemic change. Efforts to improve workers' standard of living are indispensable and should not be abandoned. However, since capitalist relations of production are the fundamental cause of workers' conditions, those efforts should be aligned with the struggles of the global working class to radically change the current mode of production.

\section{Conclusion}

By analysing the powers of Australian retail workers, this article has demonstrated that the threedimensional view on power has the capacity not only to assess workers' power in direct, day-today struggles but also to highlight and assess the systemic causes and effects of those struggles. Analysis along the first two dimensions can be used to evaluate workers' powers in direct confrontations and agenda-setting. This type of analysis could significantly benefit from being complemented with the power resources approach to clearly evaluate the current situation and to devise strategies for future action. Assessing workers' powers along the third dimension can help question the aims of struggles and better place the conflicts in the broader, class-based context.

From the Lukesian perspective on power, the first dimension confirms that in direct conflicts, large retailers have abundant material resources but workers have the capacity to disrupt the workflow at critical points or to provoke consumer boycotts. Individual small retailers might be more vulnerable to workers' militancy but usually avoid bargaining and only provide the statutory minimum set out by the industrial relations system.

The industrial relations system and other national and international legislative frameworks set the background of the second dimension of workers' power, determining the topics, scopes and scales of negotiations, bargaining and conflicts. While the frameworks that apply to Australian retail workers are not pro-labour per se, they still offer potential for improving their conditions. Moreover, they are themselves the results of power struggles between workers and employers.

Assessing the third dimension of power is less straightforward because it concerns latent conflicts, real interests, social structures and systemic effects. For retail workers, this dimension is related to the interests and preferences of other actors as well as the theoretical and ideological foundations of public and policy debates. Some of the key theoretical foundations from which these are framed, particularly neoclassical economics, are, at least implicitly, biased towards the 
interests of capital. Considered as individuals, in terms of their age, education and skills, retail workers' ability to change the balance of power along the third dimension seems quite restricted. But viewed in broader social and class terms, considering the retail workforce's diversity, regular contact with the entire population as consumers and their extended connections with millions of workers in many other countries, these workers can potentially involve other actors such as academics, journalists, activists and public figures to summon support. While detailed strategies require assessing particular campaigns and issues, perhaps by employing the PRA as a complementary framework, it is clear that the main source of retail workers' power is that they belong to the global working class. By tapping into this source, not only can they form the interests and preferences of the wider community but also improve the possibility of winning direct conflicts and institutional support.

\section{REFERENCES}

Australian Broadcasting Corporation (ABC) (2017) Sunday and Public Holiday Penalty Rates will be Reduced for Hospitality, Retail Workers, Fair Work Commission Rules. Australian Broadcasting Corporation, 24 February 2017. https://www.abc.net.au/news/2017-02-23/weekend-penalty-ratesfair-work-commission-decision/8295758 [accessed 9 May 2020].

Australian Bureau of Statistics (ABS) (2015) Retail Trade (December 2014). Cat. no. 8501.0. Canberra: Australian Bureau of Statistics.

Australian Bureau of Statistics (ABS) (2017a) Retail Trade (December 2016). Cat. no. 8501.0. Canberra: Australian Bureau of Statistics.

Australian Bureau of Statistics (ABS) (2017b). Employee Earnings and Hours, Australia, May 2016. Cat. no. 6306.0. Canberra: Australian Bureau of Statistics.

Australian Bureau of Statistics (ABS) (2018a) Labour Force, Australia, Detailed, Quarterly (May 2018). Cat. no. 6291.0.55.003. Canberra: Australian Bureau of Statistics.

Australian Bureau of Statistics (ABS) (2018b) Australian Industry, 2016-17. Cat. no. 8155.0. Canberra: Australian Bureau of Statistics.

Australian Bureau of Statistics (ABS) (2018c) Labour Force, Australia, Detailed, Quarterly (Aug 2018). Cat. no. 6291.0.55.003. Canberra: Australian Bureau of Statistics.

Australian Bureau of Statistics (ABS) (2018d) Characteristics of Employment, Australia, August 2018. Cat. no. 6333.0. Canberra: Australian Bureau of Statistics.

Australian Bureau of Statistics (ABS) (2018e) Gender Indicators, Australia, Sep 2018. Cat. no. 4125.0. Canberra: Australian Bureau of Statistics.

Australian Bureau of Statistics (ABS) (2018f) Average Weekly Earnings (May 2018). Cat. no. 6302.0. Canberra: Australian Bureau of Statistics.

Australian Bureau of Statistics (ABS) (2018g). Australian National Accounts: National Income, Expenditure and Product (March Quarter 2018). Cat. no. 5206.0. Canberra: Australian Bureau of Statistics.

Australian Bureau of Statistics (ABS) (2018h) Labour Force (June 2018). Cat. no. 6202.0. Canberra: Australian Bureau of Statistics.

Australian Bureau of Statistics (ABS) (2019) Employee Earnings and Hours, Australia, May 2018. Cat. no. 6306.0. Canberra: Australian Bureau of Statistics.

Australian Council of Social Service (ACOSS) (2012) Submission to Independent Inquiry into Insecure Work in Australia. Sydney: Australian Council of Social Service. 
Australian Council of Trade Unions (ACTU) (2018) Affiliates and TLCs. https://www.actu.org.au/aboutthe-actu/affiliates-and-tlcs [accessed 25 August 2018].

Australia Parliament House (APH) (2018a) Parliamentary Profile: Hon Michael Danby MP. www.aph.gov.au/Senators_and_Members/ Parliamentarian?MPID=WF6.

Australia Parliament House (APH) (2018b) Parliamentary Profile: Hon Tony Burke MP. www.aph.gov.au/Senators_and_Members/Parliamentarian?MPID=DYW.

Australian Small Business and Family Enterprise Ombudsman (ASBFEO) (2016) Small Business Counts: Small Business in the Australian Economy. http://www.asbfeo.gov.au/ research/small-business-counts [accessed 9 May 2020].

Bailey, J., R. Price, A. Pyman and J. Parker (2015) Union Power in Retail: Contrasting Cases in Australia and New Zealand. New Zealand Journal of Employment Relations, 40(1): 1-18.

Bieler, A. and A.D. Morton (2001) The Gordian Knot of Agency - Structure in International Relations: A Neo-Gramscian Perspective. European Journal of International Relations, 7(1): 5-35.

Bingham, F. (2016) Economic Activity of Majority Foreign Owned Businesses in Australia. Canberra: Economic Analysis Branch, Department of Foreign Affairs and Trade.

Bingham, F. (2017) Economic Activity of Australian Majority Owned Businesses Located in the European Union, New Zealand and the United States. Canberra: Economic Analysis Branch, Department of Foreign Affairs and Trade.

Campbell, I. and R. Price (2016) Precarious Work and Precarious Workers: Towards an Improved Conceptualisation. The Economic and Labour Relations Review, 27(3): 314-332.

Castells, M. (2010) The Rise of the Network Society. Second edition. Chichester, West Sussex: Wiley-Blackwell.

Coorey, P. (2017) Unions Need to Link Wage Rises to Economic Growth, says Wayne Swan. The Australian Financial Review, 25 June 2017. https://www.afr.com/news/economy/workers-must-demand-greatershare-of-pie-says=rba-governor-philip-lowe-20170619-gwtxht [accessed 9 May 2020].

Coulter, K. (2014) Revolutionizing Retail: Workers, Political Action, and Social Change. Basingstoke, UK: Palgrave Macmillan.

Dahl, R.A. (1957) The Concept of Power. Behavioral Science, 2(3): 201-215.

Deloitte (2017) Global Powers of Retailing 2017: The Art and Science of Customers. London: Deloitte Touche Tohmatsu Limited.

Department of Education, Employment and Workplace Relations (DEEWR)(2012) Towards More Productive and Equitable Workplaces: An Evaluation of the Fair Work Legislation. Canberra: DEEWR.

Department of Immigration and Border Protection (DIBP) (2014) The Place of Migrants in Contemporary Australia. Canberra: DIBP.

Dunn, B. (2004) Global Restructuring and the Power of Labour. New York: Palgrave Macmillan.

Dunn, B. (2010) Economic Change and Labour's Decline: An Empirical Qualification concerning Their Association. Paper presented to the Global Labour University Conference, Berlin, 14-16 September.

Fair Work Commission (FWC) (2013) Retail Trade Industry Profile. Research Report 4/2013. Melbourne: FWC.

Fair Work Ombudsman (2018) Awards. https://www.fairwork.gov.au/awards-and-agreements/awards [accessed 16 December 2018].

Fair Work Ombudsman (2019a) Minimum Wages. https://www.fairwork.gov.au/pay/penalty-rates-andallowances [accessed 13 July 2019]. 
Fair Work Ombudsman (2019b) National Employment Standards. https://www.fairwork.gov.au/employeeentitlements/national-employment-standards [accessed 26 January 2019].

Fair Work Ombudsman (2019c) Penalty Rates and Allowances. https://www.fairwork.gov.au/ pay/penaltyrates-and-allowances [accessed 16 February 2019].

Gallas, A. (2018) Class Power and Union Capacities: A Research Note on the Power Resources Approach. Global Labour Journal, 9(3): 348-352.

Global Labour Journal (GLJ) (2016) Special Issue: The Politics of Precarity - Critical Engagements with Guy Standing. Global Labour Journal, 7(2), May 2016. https://mulpress.mcmaster.ca/global labour/issue $\angle$ view/292.

Greber, J. (2017) We'd Love to Pay People More - But Not Anytime Soon, Says BCA President. The Australian Financial Review, 20 June 2017. https://www.afr.com/policy/economy/wed-love-to-paypeople-more-but-not-anytime-soon-says-bca-president-20170620-gwuu4p [accessed 9 May 2020].

Hannan, E. (2019) Penalty Rate Cut 'Failed to Create One New Job'. The Australian, 26 April 2019. https://www.theaustralian.com.au/nation/politics/penalty-rate-cut-failed-to-create-one-newjob/news-story/4946a1915162c197a896063ae4009bb7 [accessed 9 May 2020].

Hay, C. (2002) Political Analysis. New York: Palgrave.

Hayward, C.R. (2000) De-facing Power. New York: Cambridge University Press.

Hayward, C. and S. Lukes (2008) Nobody to Shoot? Power, Structure, and Agency: A Dialogue. Journal of Power, 1(1): 5-20.

Hyman, R. (2001) Understanding European Trade Unionism: Between Market, Class and Society. London: Sage.

Holgate, J. (2015) An International Study of Trade Union Involvement in Community Organizing: Same Model, Different Outcomes. British Journal of Industrial Relations, 53(3): 460-483.

International Labour Organization (ILO) (2011) Adapting Work Processes and Working Environments in Retail Commerce to Older Workers' Needs. Geneva: ILO.

International Labour Organization (ILO) (2015) Employment Relationships in Retail Commerce and Their Impact on Decent Work and Competitiveness. Geneva: ILO.

Isaac, J.C. (1987) Beyond the Three Faces of Power: A Realist Critique. Polity, 20(1): 4-31.

Jessop, B. (2012) Marxist Approaches to Power. In The Wiley-Blackwell Companion to Political Sociology, edited by E. Amenta, K. Nash and A. Scott. Chichester: Wiley.

Luce, S. (2013) Global Retail Report. Buenos Aires: UNI Global Union.

Lukes, S. (2005) Power: A Radical View. Second edition. Hampshire: Palgrave Macmillan.

Nigam, A. (1996) Marxism and Power. Social Scientist, 24(4/6): 3-22.

Nowak, J. (2018) The Spectre of Social Democracy: A Symptomatic Reading of the Power Resources Approach. Global Labour Journal, 9(3): 353-360.

Office of Parliamentary Counsel (2010) Competition and Consumer Act 2010. https://www.legislation.gov.au/Details/C2011C00003 [accessed 21 May 2020].

Palermo, G. (2016) Economics and Power: A Marxist Critique. New York: Routledge.

Price, R., J. Bailey and A. Pyman (2014) Varieties of Collaboration: The Case of an Australian Retail Union. The International Journal of Human Resource Management, 25(6): 748-761.

Productivity Commission (2011) Economic Structure and Performance of the Australian Retail Industry. Report no. 56. Canberra: Australian Government. 
Productivity Commission (2015) Workplace Relations Framework. Report no. 76. Canberra: Australian Government.

Ruetschlin, C. (2012) Retail's Hidden Potential. New York: Demos.

Schmalz, S., C. Ludwig and E. Webster (2018) The Power Resources Approach: Developments and Challenges. Global Labour Journal, 9(2): 113-134.

Shop, Distributive and Allied Employees' Association (SDA) (2017a) Annual Financial Report 2017. https://www.sdaq.asn.au/app/uploads/2016/09/2017-SDA-National-Accounts.pdf [accessed 24 July 2018].

Shop, Distributive and Allied Employees' Association (SDA) (2017b) Submission: Senate Inquiry into Penalty Rates in the Retail, Hospitality, and Fast Food Sectors, Canberra. https://www.aph.gov.au/ DocumentStore.ashx?id=7f5672d5-884b-41f7-a429-d5c7b61f8e14\&subId=513661 $\quad$ accessed 20 August 2018].

Shop, Distributive and Allied Employees' Association (SDA) (2018) Submission: Senate Inquiry into the Operation and Effectiveness of the Franchising Code of Conduct, Melbourne. https://www.sda.org.au/download/ submissions-publications/Senate-Inquiry-into-the-Operation-and-Effectiveness-of-the-FranchisingCode-of-Conduct.pdf [accessed 3 December 2018].

Shaikh, A. (2016) Capitalism: Competition, Conflict, Crises. New York: Oxford University Press.

Silver, B.J. (2003) Forces of Labor: Workers' Movements and Globalization since 1870. New York: Cambridge University Press.

Sklair, L. (2016) The Transnational Capitalist Class, Social Movements, and Alternatives to Capitalist Globalization. International Critical Thought, 6(3): 329-341.

Standing, G. (2016) The Precariat: The New Dangerous Class. London: Bloomsbury.

UNI Global Union (2018) About Us. https://www.uniglobalunion.org/about-us [accessed 26 August 2018].

Wesfarmers (2017a) Annual Report 2017. http://www.wesfarmers.com.au/investor-centre/companyperformance-news/reports [accessed 13 August 2018].

Wesfarmers (2017b) Sustainability Report 2017. sustainability.wesfarmers.com.au [accessed 13 August 2018].

Wesfarmers (2018) Annual Report 2018. https://www.wesfarmers.com.au/docs/default-source/asxannouncements/2018-annual-report.pdf [accessed 17 July 2018].

Wood, A. (1995) North-South Trade, Employment, and Inequality Changing Fortunes in a Skill-driven World. Oxford: Clarendon.

Woolworths Group (2017) Corporate Responsibility Report. https://wow2017cr.qreports.com.au [accessed 13 August 2018].

Woolworths Group (2018) Annual Report 2018. https://www.woolworthsgroup.com.au/icms docs/ 195396 annual-report-2018.pdf [accessed 21 August 2018].

Zajak, S. (2017) International Allies, Institutional Layering and Power in the Making of Labour in Bangladesh. Development and Change, 48(5): 1007-1030.

\section{ACKNOWLEDGEMENTS}

I am grateful to Associate Professor Bill Dunn for his invaluable support and advice throughout my research project. I would also like to thank the two anonymous reviewers and the GLJ's editors for their helpful and constructive feedback. 


\section{BIOGRAPHICAL NOTE}

PoOya KarambakHSH is a PhD candidate in Political Economy at the University of Sydney, Australia. [Email: pooya.karambakhsh@sydney.edu.au] 